\title{
COELIAC DISEASE IN CHILDREN WITH DOWN SYNDROME IN SERBIA
}

\author{
Momcilo Pavlović ${ }^{1}$, Bogdan Arsić ${ }^{2}$, Bratislav Kazić ${ }^{3}$ \\ ${ }^{1}$ Pediatric Department, General Hospital Subotica, Subotica, Serbia \\ ${ }^{2}$ Department of Infectious Diseases, General Hospital Subotica, Subotica, Serbia \\ ${ }^{3}$ Pediatric Department, General Hospital Vrbas, Vrbas, Serbia
}

\section{CELIJAČNA BOLEST IKOD DECE SA DAUNOVIM SINDROMOM U SRBIJI}

\author{
Momčilo Pavlović ${ }^{1}$, Bogdan Arsić ${ }^{2}$, Bratislav Kazić \\ Služba za pedijatriju, Opšta bolnica Subotica, Subotica, Srbija \\ ${ }^{2}$ Odeljenje za infektivne bolesti, Opšta bolnica Subotica, Subotica, Srbija \\ Služba za pedijatriju, Opšta bolnica Vrbas, Vrbas, Srbija
}

Received / Primljen: 13. 02. 2012.

Accepted / Prihvaćen: 03. 04. 2012

\begin{abstract}
Introduction. To determine the prevalence of coeliac disease (CD) in children with Down syndrome (DS) in Serbia and to analyse the clinical characteristics and laboratory data from patients with $D S$.

Methods. A total of 91 children (50 boys and 41 girls, mean age of 6.3 years) with DS were examined. The total levels of IgA and IgA transglutaminase (IgA tTG) antibodies were determined. The levels of IgG transglutaminase (IgG tTG) and IgG anti-endomysial (IgG EMA) antibodies were determined in cases of IgA immunodeficiency. Enterobiopsies were performed in patients with positive antibody titres.

Results. Of the children evaluated, 38 exhibited constipation (41.7\%), 26 experienced vomiting and regurgitation (28.5\%), 16 had anaemia (17.5\%), and two had intermittent diarrhoea (2.2\%). The DS-specific mean weight percentile was $15.2 \% \pm 14.5 \%$ (range $<5-75 \%$ ). In four out of five of the children with positive levels of IgA tTG, an enterobiopsy showed the presence of CD (4.4\%, 95\% CI, 1.7\%-10.7\%). The levels of IgG tTG and IgG EMA were determined in five children with an IgA immunodeficiency. The IgG EMA was negative in all five of the children. Three of the children showed increased IgG tTG values and underwent an enterobiopsy, which showed a normal mucosa. Our analysis shows that the signs and symptoms of CD in children with DS are only of minor diagnostic value in the detection of the disease.
\end{abstract}

Conclusion. These results suggest the need for systematic screening for $C D$ in children with DS because symptoms that are characteristic of both diseases may overlap.

Keywords: anti-endomysial antibodies; coeliac disease; Down syndrome; tissue transglutaminase antibodies

\section{SAŽETAK}

Uvod. Odrediti prevalenciju celijačne bolesti $(C B)$ i analizirati kliničke karakteristike i laboratorijske nalaze kod dece sa Daunovim sindromom (DS) u Srbiji.

Metode. Ispitivano je devedeset jedno dete (50 dečaka i 41 devojčica, prosečne starosti 6,3 godine) određivanjem ukupnih vrednosti IgA i IgA transglutaminskih At (IgA TTG), a u slučajevima IgA imudodeficijencije $i$ odredivanjem IgG transglutaminskih At (IgG TTG) i IgG andiendomizijalnih At (IgG EMA). Kod seropozitivne dece je radena enterobiopsija.

Rezultati. Četrdeset jedno dete je imalo konstipaciju (41,7\%), 26 povraćanje i regurgitaciju (28,5\%), 16 anemiju (17,5\%), dok je dvoje dece imalo povremeni dijarealni poremećaj (2,2\%). Prosečan percentil težine određivan tablicama $z a$ decu sa DS je iznosio $15.2 \% \pm 14.5 \%$ (range $<5-75 \%$ ). Kod četvoro od petoro dece sa pozitivnim IgA TTG je enterobiopsijom dokazana CB (4,4\%, 95\% CI, 1.7\%-10.7\%). Kod petoro dece je utvrdena IgA imudodeficijencija $i$ kod njih su odredivana IgG TTG i IgG EMA. IgA EMA su bila negativna u svo petoro dece, dok su kod troje dobijene povišene vrednosti IgG TTG. Kod ovo troje je urađena enterobiopsija koja je ukazala na postojanje sluznice normalnih karakteristika. Znaci $i$ simptomi koji su karakteristični za CB kod naše dece sa DS su imali malu dijagnostičku vrednost.

Zaključak. Naši rezultati ukaziju na potrebu za sistematskim skriningom za CB kod dece sa DS.

Ključne reči: antiendomizijalna antitela; celijačna bolest; Daunov sindrom; transglutaminska antitela

Abbreviations: CD - coeliac disease, DS - Down syndrome, IgA tTG - immunoglobulin A transglutaminase antibodies, IgG tTG - immunoglobulin G transglutaminase antibodies, IgG EMA - immunoglobulin G anti-endomysial antibodies. 


\section{INTRODUCTION}

Down syndrome (DS) is a chromosomal disorder that results from trisomy and other aberrations of chromosome 21 . With a prevalence of 1:700, DS represents the most common chromosomal disorder and is a leading cause of mental retardation (1). DS is characterised by multiple typical somatic and visceral malformations and an increased risk of infection, leukaemia, and autoimmune diseases, such as hypothyroidism, Hashimoto's thyroiditis, diabetes mellitus type 1 and coeliac disease (CD) (2).

The association between $\mathrm{CD}$ and DS was first described more than 30 years ago (3). Many papers published since then have reported the prevalence of $C D$ in patients with DS to range from $2.5 \%$ to $18.6 \%$ (4-7). Several medical associations have concluded that serological screening for $\mathrm{CD}$ should be performed in all children with DS and have issued appropriate recommendations and guidelines in the light of the possibility that developing lymphoma is the most severe complication of $C D(8,9)$. However, there are authors who believe that the consistent use of this approach might not be entirely justified, primarily for economic reasons (10).

The prevalence of CD in children with DS in Serbia has not yet been reported. The available data on the prevalence of CD in Serbia are from two studies. The first study was limited to children with a classic form of CD in the Province of Voyvodina (the north part of Serbia), which showed an incidence rate of 1 in 1715 live births (11). A recent article that included 121 children with type 1 diabetes mellitus in Serbia reported the prevalence of CD to be $5.8 \%$ (12).

The aim of the present study was to determine the prevalence of CD in children with DS in Serbia and to evaluate the clinical signs that might assist in the diagnosis of CD.

\section{PATIENTS AND METHODS}

\section{Patients}

A total of ninety-one children with DS were evaluated in the Pediatric Department at the General Hospital Subotica from October 2004 to January 2011. Children from all regions of Serbia were evaluated at the Facility for Children with Developmental Disorders "Kolevka" in Subotica. Trisomy of chromosome 21 was confirmed in all of the children by karyotype analysis. The age of the children with Down syndrome ranged from 8 months to 16 years (mean age of 6.3 years The male to female ratio was 1.2 (50 boys/41 girls). The body mass was determined based on the DS-specific mean weight percentile (13). Gastrointestinal functions that are specific to CD, such as chronic diarrhoea, constipation, vomiting, failure to thrive and associated anomalies that are characteristic of DS, were recorded. A complete blood count, serum iron, and hepatic transaminase levels were determined for all of the children.

\section{Serologic Markers}

After approval of the research by the Hospital Ethics Committee, all of the patients were tested to determine the immunoglobulin A (IgA) tissue transglutaminase (tTG) and total IgA levels. In cases of low total IgA levels, the immunoglobulin G (IgG) tTG and IgG anti-endomysial (EMA) levels were evaluated.

IgA tTG and IgG tTG were measured using a commercial enzyme-linked immunosorbent assay (Orgentec Diagnostika, Mainz, Germany). Values $\geq 10 \mathrm{U} / \mathrm{mL}$ were considered to be positive, as recommended by the manufacturer. Quantitative determinations of serum IgA levels were performed using a routine method.

In cases of IgA deficiency, sera were analysed for IgG EMA antibodies. IgG EMA antibodies were determined using an immunofluorescence method on a primate oesophagus substrate (IMMCO Diagnostics, Buffalo, New York).

\section{Small Bowel Histology}

The patients who were serologically positive for $\mathrm{CD}$ were scheduled for an upper endoscopy to biopsy the duodenum. Specimens of the mucosa were collected from the descendent duodenum and bulb (four biopsies) and sent for histopathological examination. Biopsies were evaluated by one pathologist who was unaware of the patients' identity. Biopsies were classified according to Marsh's (14) criteria, as revised by Oberhuber (15).

\section{Statistical Analysis}

Categorical variables are presented as absolute and relative frequencies, whereas continuous variables are summarised as the mean \pm SD. Student's $t$ tests were used to evaluate the continuous data. Children with both DS and $\mathrm{CD}$ were compared to children without $\mathrm{CD}$. The rejection of the null hypothesis was set at $5 \%(P<0.05)$.

\section{RESULTS}

The Down syndrome-specific mean weight percentile of the 91 children evaluated was $15.2 \% \pm 14.5 \%$ (range $<5-75 \%$ ). Out of 91 children with DS, 54 had malformations (59.3\%). Forty of the children exhibited constipation $(41.7 \%, 95 \% \mathrm{CI}$, $34.2 \%-54.2 \%), 27$ experienced vomiting and regurgitation (28.5\%, 95\% CI, 21.2\%-39.7\%), 16 had sideropenic anaemia (17.5\%, 95\% CI, 10.3\%-24.4\%) and two had an intermittent diarrhoeal disorder (2.2\%, 95\% CI, 0.6\%-7.6\%).

IgA tTG and total IgA levels were determined for all of the children. Increased levels of IgA tTG were found in 5 of the children (5.5\%) with DS. Three of the 5 were diagnosed with sideropenic anaemia, one had alopecia, and one was asymptomatic. In 4 out of 91 (4.4\%) children (e.g., the three children with sideropenic anaemia and the child with alopecia), the pathohistological analysis of the duodenal mucosa sample showed that 2 of the patients had partial villous atrophy (Marsh 3a) and two had severe villous atrophy (Marsh 3b and Marsh 3c). In the asymptomatic child with increased levels of IgA tTG, the mucosa of the small intestine showed normal pathohistological characteristics (Table 1). Out of the four children with confirmed gluten 


\begin{tabular}{|l|l|l|l|l|l|l|}
\hline Patient & Sex & Age & Diseases & GI symptoms & $\begin{array}{l}\text { IgA tTG lev- } \\
\text { els }\end{array}$ & Biopsy \\
\hline 1 & M & 16 years, 2 months & Alopecia & Constipation & $102.5 \mathrm{U} / \mathrm{mL}$ & Marsh $3 \mathrm{a}$ \\
\hline 2 & M & 6 years, 1 month & $\begin{array}{l}\text { Sideropenic anaemia, } \\
\text { AV septal defect }\end{array}$ & Vomiting & $60 \mathrm{U} / \mathrm{mL}$ & Marsh $3 \mathrm{~b}$ \\
\hline 3 & $\mathrm{M}$ & 6 years & Sideropenic anaemia & None & $88 \mathrm{U} / \mathrm{mL}$ & Marsh $3 c$ \\
\hline 4 & F & 7 years, 3 months & $\begin{array}{l}\text { Sideropenic anaemia, } \\
\text { AV canal }\end{array}$ & Constipation & $45 \mathrm{U} / \mathrm{mL}$ & Marsh $3 a$ \\
\hline 5 & F & 3 years, 8 months & None & None & $17.7 \mathrm{U} / \mathrm{mL}$ & Normal \\
\hline
\end{tabular}

Table 1. Positive results of screening and the diseases associated with Down syndrome in children

\begin{tabular}{|c|c|c|c|}
\hline & DS patients without $\mathrm{CD}(\mathrm{N}=\mathbf{8 7})$ & DS patients with $\mathrm{CD}(\mathrm{N}=4)$ & $P$ \\
\hline Weight, perc. $($ mean \pm SD) & $14.9 \pm 14.4$ & $23.8 \pm 18.9$ & 0.233 \\
\hline \multicolumn{4}{|l|}{ Laboratory findings } \\
\hline Haemoglobin $(\mathrm{g} / \mathrm{dL})$ & $11.3 \pm 1.3$ & $9.3 \pm 1.4$ & 0.005 \\
\hline Mean corpuscular volume (fL) & $84.6 \pm 8.2$ & $79.3 \pm 4.2$ & 0.197 \\
\hline Serum iron $(\mu \mathrm{mol} / \mathrm{L})$ & $14.3 \pm 6.2$ & $11.4 \pm 9.1$ & 0.37 \\
\hline Alanine transaminase (UI/L) & $23 \pm 7$ & $24 \pm 8$ & 0.618 \\
\hline Aspartate transaminase (UI/L) & $23 \pm 9$ & $25 \pm 8$ & 0.765 \\
\hline
\end{tabular}

Table 2. Clinical characteristics and laboratory test results for Down syndrome patients without coeliac disease $(\mathrm{n}=87)$ and Down syndrome patients with $\mathrm{CD}(\mathrm{n}=4)$.

enteropathies, two of them had constipation and one intermittently suffered from vomiting and regurgitation. Gluten enteropathy was found in 4 out of 5 of the children with positive levels of IgA tTG antibodies (80\%). The prevalence of $C D$ in this population was $4.4 \%$, with a confidence interval (95\%) ranging from $1.7 \%$ to $10.7 \%$.

Low levels of IgA $(0.05-0.1 \mathrm{~g} / \mathrm{L})$ were found in 5 of the patients $(5.49 \%)$. Due to the low levels of total IgA, these children were also tested for IgG tTG levels and IgG EMA antibodies. In all five of the children, the IgG EMA was negative. Increased levels of IgG tTG were found in three out of five of the children (28-36 U/mL). An enterobiopsy was performed and showed the presence of a normal mucosa.

A comparative analysis between the patients with diagnosed CD based on biopsy results and children without $C D$ (Table 2) revealed that there were no statistically significant differences in the results of the aminotransferase and hematologic tests, except that patients with DS and CD tended to have significantly lower haemoglobin levels $(\mathrm{P}=0.005)$.

\section{DISCUSSION}

The prevalence of children with DS and CD in Serbia (4.4\%), which is higher than in the general population, is in agreement with the rates observed in many other countries, including Europe (e.g., 2.6\% in Germany, $4.5 \%$ in the Netherlands, $4.6 \%$ in Italy, $6.3 \%$ in Spain, and $6.4 \%$ in Turkey), North America (e.g., $2.6 \%$ to $6.6 \%$ in the USA),
South America (e.g., 3.6\% in Argentina and 5.6\% in Brazil), the Middle East (e.g., 3.8\% in Israel), and Australia (3.9\%) (4-6,16-23). The reported rates are likely underestimated because most of authors from the other studies did not perform small bowel biopsies or additional confirmatory laboratory testing (EMA or HLA-DQ2 and HLA-DQ8 typing) in the patients with DS who had a positive serology. Differences in the type of antibody used for screening and cohort size may have influenced the variability in the rates of occurrence. A higher prevalence was reported in two smaller series from Sweden. Jansson and Johansson (24) screened 65 patients with DS and found a CD prevalence of $16.9 \%$, while Carlsson et al. (7) reported a similar prevalence of $18.6 \%(8 / 43)$. These regional differences raise questions about geographic and ethnic influences on the development of CD in patients with DS (Table 3).

$\mathrm{CD}$ can present as symptomatic and asymptomatic forms with clinical, serologic and pathohistological variations. In children with DS and symptomatic CD, growth failure, anaemia, intermittent diarrhoea, and constipation are described as the most common manifestations of the disease $(7,8)$. The significance of these manifestations in clinical practice is not entirely obvious because the same signs can occur in children with DS that do not have CD (4).

The majority of children in this study with DS without CD presented with gastrointestinal symptoms that are typical for both diseases. Congenital heart defects, untreated $\mathrm{CD}$ and hypothyroidism might influence the growth and weight (between $0.5-2 \mathrm{~kg}$ ) of children with DS (25). Growth 


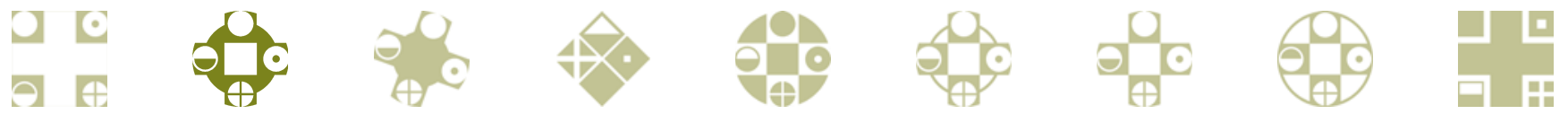

\begin{tabular}{|l|l|l|l|l|l|}
\hline Country & Prevalence & Author (reference) & No & Serologic markers & $\begin{array}{l}\text { Biopsies } \\
\text { in all } *\end{array}$ \\
\hline Germany & $2.6 \%$ & Storm $(5)$ & 78 & IgA and IgG AGA & No \\
\hline USA & $3.2 \%$ & Mackey et al. (18) & 93 & IgA EMA,AGA and IgG AGA & No \\
\hline Argentina & $3.6 \%$ & Rumbo et al. (17) & 56 & IgA EMA,AGA,tTG and IgG AGA, tTG & Yes \\
\hline Israel & $3.8 \%$ & Shamaly et al. (16) & 52 & IgA EMA,AGA,tTG and IgG AGA, tTG & No \\
\hline Australia & $3.9 \%$ & Gale et al. (19) & 55 & IgA and IgG AGA & No \\
\hline Netherlands & $4.5 \%$ & Wouters et al. (20) & 155 & IgA EMA and IgA tTG & Yes \\
\hline Italy & $4.6 \%$ & Bonamico et al. (4) & 1202 & IgA EMA and IgA AGA & No \\
\hline Brazil & $5.6 \%$ & Nisihara et al. (21) & 71 & IgA EMA and IgA tTG & No \\
\hline Spain & $6.3 \%$ & Carnicer et al. (23) & 284 & IgA EMA,AGA and IgG EMA, AGA & Yes \\
\hline Turkey & $6.4 \%$ & Cogulu et al. (6) & 47 & IgA EMA and IgA AGA & No \\
\hline USA & $6.6 \%$ & Zachor et al. (22) & 75 & IgA EMA and IgA AGA & No \\
\hline Sweden & $16.9 \%$ & Jansson et al. (24) & 65 & IgA EMA and IgA AGA & No \\
\hline Sweden & $18.6 \%$ & Carlsson et al. (7) & 43 & IgA EMA and IgA AGA & No \\
\hline
\end{tabular}

Table 3. Prevalence of coeliac disease in children with Down syndrome

EMA, anti-endomysial antibodies; AGA, antigliadin antibodies; tTG, tissue transglutaminase antibodies; IgA, immunoglobulin A; IgG immunoglobulin G; *Author and the reference number; **: Biopsies were performed in all of the patients with positive serology.

failure as a manifestation of CD loses its significance in children with DS because some of the associated malformations (as observed in almost half of our patients, with a weight percentile of $15.2 \%$ ) may also have the same effect.

We found that aminotransferases and hematologic tests did not predict the coexistence of CD in the children with DS. Although the patients with $C D$ tended to have lower haemoglobin levels $(\mathrm{P}=0.005), \mathrm{CD}$ was the cause of anaemia in only three out of 16 cases, and its value as an indicator of CD is clearly relative in children with DS.

Until recently, there has been a lack of standard evidence-based guidelines for the universal screening of children with DS for CD. The Healthcare Guidelines for Patients with DS, which was developed by the American Academy of Pediatrics, has not made any recommendations for CD screening (26). The Down's Syndrome Medical Interest Group recommends one screening between the ages of 2 to 3 years (9), while the North American Society for Pediatric Gastroenterology, Hepatology and Nutrition (NASPGHAN) has suggested that screening children with DS once in a lifetime is not enough and that periodic screening should be performed (8). The latest guidelines from the European Society for Paediatric Gastroenterology, Hepatology and Nutrition (ESPGHAN) for the diagnosis of CD (27) state that human leukocyte antigen (HLA) testing should be performed in children with CD-associated conditions such as DS. If certain haplotypes are negative (e.g., HLA-DQ2 and HLA-DQ8), no further follow-ups with serological tests are necessary. If HLA testing is not available, the anti-TG2 IgA and the total IgA should be measured after the child is 2 years old. If titres of these antibodies are negative, then repeated testing for $\mathrm{CD}$-specific antibodies is recommended. How- ever, the recommended frequency of repeated testing has not been stated unequivocally.

Several antibody markers of $C D$ can be used for screening. Due to their sensitivity and specificity, the tTG and EMA antibodies have been commonly used in recent years to screen children with DS and the general population for CD. In this study, out of the five patients that were IgA tTG positive, gluten enteropathies were identified in four of the children (80\%). It is not surprising that the biopsy in one of the patients with a positive IgA tTG was normal because the elevation of IgA tTG in that case was mild $(17.7 \mathrm{U} / \mathrm{ml})$. Our findings are similar to Hansson et al. (28), who tested 52 patients with DS and reported a $98 \%$ sensitivity for IgA tTG, which is comparable to the results reported by Shamaly and colleagues (16). In contrast, Cerqueira et al. (29) screened 98 Portuguese patients with DS and diagnosed CD in only five out of the 10 (50\%) patients who were IgA tTG positive. The study was performed both in children and adults, which could explain the difference in the results, and the author reported that the sensitivity of IgA tTG was lower in older patients.

According to the ESPGHAN guidelines, unnecessary biopsies in individuals with low CD-specific antibody levels could be avoided by using a more specific test for EMA. If the EMA test is positive, duodenal biopsies should be performed. If the EMA test is negative, repeated serological testing at 3 to 6 month intervals is sufficient (27).

Given that the incidence of IgA deficiency in patients with CD is 3\% (30), IgA levels were determined for all of the children. IgA deficiencies were detected in 5 (5.5\%) of the patients, which represents a high prevalence. In our small study, three out of five of the patients with IgA deficiencies showed increased IgG tTG values, but the mucosa showed normal histological char- 
acteristics and the IgG EMA values were negative. Data from this study showed that the IgG EMA is a more reliable marker compared to the IgG tTG. Rumbo et al. (17) compared the efficiency of different serological markers and demonstrated the high diagnostic efficiency of IgA tTG and EMA with a large number of false positive IgG tTG results ( 9 out of 56 children with DS). However, EMA determination in children under 2 years of age is more difficult, expensive, and less accurate, and the results can vary depending on the investigator (31).

Our findings can be interpreted from the perspective that the normal mucosa in children with positive tTG antibody levels does not necessarily signify the absence of $C D$ because it may be a prognostic sign of forthcoming mucosal villous atrophy (latent $C D$ ). A missed diagnosis can lead to the possibility of developing a malignancy as a late complication, such as enteropathy-associated T-cell lymphoma. Serological monitoring of these children can provide additional diagnostic data, but the frequency of screening remains questionable. We agree with Mackey et al. (18), who suggests yearly CD screenings for patients with DS who are serologically positive and biopsy negative.

The patients with CD in this study were treated with a strict gluten-free diet followed by an orally administered correction of any iron deficits for 3-4 months in the cases of children with anaemia. The levels of IgA tTG after 12 months were normal in all four patients. However, the issues with constipation did not resolve and additional dietetic therapeutic measures were undertaken, which moderately improved the common symptoms of constipation in the patients with DS. In patients with alopecia, the administration of a gluten-free diet had no effect on hair growth.

There are several limitations to this study. First, this study included a small sample size of patients who resided in a public health-care institution, many of whom had serious medical problems. Second, the prevalence of CD in the children with DS may have been underestimated because we did not perform IgA EMA screening for economic and ethical reasons (e.g., patients with a negative serology enterobiopsy). Finally, we did not perform HLA haplotyping analysis. HLA-DQ typing is planned in future studies, which could allow the exclusion of further investigations.

\section{CONCLUSIONS}

This prospective study shows that the prevalence of CD in children with DS in Serbia is 4.4\%, which is similar to the findings of previous studies. Because children with DS who do not have villous atrophy but present with a positive serology may have latent $C D$, the prevalence of $C D$ in these patients may be even higher. Our analysis shows that the signs and symptoms of CD in children with DS only have minor diagnostic value for detecting the disease and that systematic screening of children with DS for CD should be considered a routine evaluation, although the optimal frequency of the screening events need to be established in future studies.

\section{REFERENCES}

1. Patton MA. Genetics. In: Mclntosh N, Helms PJ, Smyth RL, editors. Forfar and Arneil's Textbook of Pediatrics. Edinburgh: Culrchill Liv; 2003. p. 407-41.

2. Bonamico $M$. Which is the best screening test for celiac disease in Down syndrome children? J Pediatr Gastroenterol Nutr 2005; 40(2):125-7.

3. Bentley D. A case of Down's syndrome complicated by retinoblastoma and celiac disease. Pediatrics 1975; 56(1):131-3.

4. Bonamico M, Mariani P, Danesi HM, et al. Prevalence and clinical picture of celiac disease in Italian Down syndrome patients: a multicenter study. J Pediatr Gastroenterol Nutr 2001; 33(2):139-43.

5. Storm W. Prevalence and diagnostic significance of gliadin antibodies in children with Down syndrome. Eur J Pediatr 1990; 149(12):833-4.

6. Cogulu O, Ozkinay F, Gunduz C, et al. Celiac disease in children with Down syndrome: importance of follow-up and serologic screening. Pediatr Int 2003; 45(4):395-9.

7. Carlsson A, Axelsson I, Borulf S, et al. Prevalence of IgA antigliadin antibodies and IgA antiendomisium antibodies related to celiac disease in children with Down syndrome. Pediatrics 1998; 101(2):272-5.

8. Hill ID, Dirks MH, Liptak GS, et al. Guideline for the diagnosis and treatment of celiac disease in children: recommendations of the North American Society for Pediatric Gastroenterology, Hepatology and Nutrition. J Pediatr Gastroenterol Nutr 2005; 40(1):1-19.

9. Cohen W. Health care guidelines for individuals with Down syndrome: 1999 revision. Down Synd 1999 Q 4:1-15.

10. Swigonski NL, Kuhlenschmidt HL, Bull MJ, Corkins MR, Downs SM. Screening for celiac disease in asymptomatic children with Down syndrome: cost-effectiveness of preventing lymphoma. Pediatrics 2006; 118(2):594-602.

11. Vukavić T: The incidence of coeliac disease in children born in the territory of Voyvodina (Serbia): Coeliac disease register 1980 1993. Arch Gastroenterohepatol 1995; 14(1-2):1-3. (Serbian)

12. Djuric Z, Stamenkovic H, Stankovic T, et al. Celiac disease prevalence in children and adolescents with type 1 diabetes from Serbia. Pediatr Int 2010; 52(4):579-83.

13. Cronk C, Crocker AC, Pueschel SM, et al. Growth charts for children with Down syndrome: 1 month to 18 years of age. Pediatrics 1988; 81(1):102-10.

14. Marsh MN: Gluten, major histocompatibility complex, and the small intestine. A molecular and immunobiologic approach to the spectrum of gluten sensitivity (celiac sprue). Gastroenterology 1992; 102(1):330-54.

15. Oberhuber G. Histopathology of celiac disease. Biomed Pharmacother 2000; 54(7):368-72.

16. Shamaly H, Hartman C, Pollack S, et al. Tissue transglutaminase antibodies are a useful serological marker for the diagnosis of celiac disease in patients with Down syndrome. J Pediatr Gastroenterol Nutr 2007; 44(5):583-6.

17. Rumbo M, Chirdo FG, Ben R, Saldungaray I, Villalobos R. Evaluation of celiac disease markers in Down syndrome patients. Dig Liver Dis 2002; 34(2):116-21. 
18. Mackey J, Treem WR, Worley G, Boney A, Hart P, Kishnani PS. Frequency of celiac disease in individuals with Down syndrome in the United States. Clin Pediatr (Phila) 2001; 40(5):249-52.

19. Gale L, Wimalaratna H, Brotodiharjo A, Duggan JM. Down's syndrome is strongly associated with celiac disease. Gut 1997; 40(4):492-6.

20. Wouters J, Weijerman ME, van Furth AM, et al. Prospective human leukocyte antigen, endomisium immunoglobulin A antibodies, and transglutaminase antibodies testing for celiac disease in children with down syndrome. J Pediatr 2009; 154(2):239-42.

21. Nisihara RM, Kotze LM, Utiyama SR, Oliveira NP, Fiedler PT, Messia-Reason IT. Celiac disease in children and adolescents with Down syndrome. J Pediatr (Rio J) 2005; 81(5):373-6.

22. Zachor DA, Mroczek-Musulman E, Brown P. Prevalence of celiac disease in Down syndrome in the United States. Pediatr Gastroenterol Nutr 2000; 31(3):275-9.

23. Carnicer J, Farre C, Varea V, Vilar P, Moreno J, Artigas J. Prevalence of coeliac disease in Down's syndrome. Eur J Gastroenterol Hepatol 2001; 13(3):263-7.

24. Jansson U, Johansson C. Down syndrome and celiac disease. Pediatr Gastroenterol Nutr 1995; 21(4):443-5.

25. Myrelid A, Gustafsson J, Ollars B, Annerén G. Growth charts for Down's syndrome from birth to 18 years of age. Arch Dis Child 2002; 87(2):97-103.
26. American Academy of Pediatrics. Committee on Genetics. American Academy of Pediatrics: Health supervision for children with Down syndrome. Pediatrics 2001; 107(2):442-9.

27. Husby S, Koletzko S, Korponay-Szabó IR, Mearin ML, Phillips A, Shamir R, Troncone R, Giersiepen K, Branski D, Catassi C, Lelgeman M, Mäki M, Ribes-Koninckx C, Ventura A, Zimmer KP; ESPGHAN Working Group on Coeliac Disease Diagnosis; ESPGHAN Gastroenterology Committee. European Society for Pediatric Gastroenterology, Hepatology, and Nutrition guidelines for the diagnosis of coeliac disease. J Pediatr Gastroenterol Nutr 2012; 54: 136-60.

28. Hansson T, Dahlbom I, Rogberg S, et al. Antitissue transglutaminase and antithyroid autoantibodies in children with Down syndrome and celiac disease. J Pediatr Gastroenterol Nutr 2005; 40(2):170-4.

29. Cerqueira RM, Rocha CM, Fernandes CD, Correia MR. Celiac disease in Portuguese children and adults with Down syndrome. Eur J Gastroenterol Hepatol. 2010; 22(7):868-71.

30. Rittmeyer C, Rhoads JM. IgA deficiency causes falsenegative endomysial antibody results in celiac disease. J Pediatr Gastroenterol Nutr 1996; 23(4):504-6.

31. Bürgin-Wolff A, Gaze H, Hadziselimovic F, et al. Antigliadin and antiendomysium antibody determination for coeliac disease. Arch Dis Child 1991; 66(8):941-7. 